Volume 2 Issue 2, July-December 2021: pp. 95-108.

Indonesian Private Law Review.

Fakultas Hukum, Universitas Lampung,

Bandar Lampung, Indonesia.

P-ISSN: 2723-259X E-ISSN: 2745-9284

https://jurnal.fh.unila.ac.id/index.php/iplr

\title{
LEGAL CERTAINTY OF THE DEED OF AGREEMENT MADE BY A NOTARY BASED ON THE POWER TO SELL (CASE STUDY CASE NUMBER: 41/PDT.G/2016/PN.PA)
}

\author{
Puspita Putri Ramadhani, ${ }^{1}$ Hasbir Paserangi, ${ }^{2}$ Wiwie Heryani ${ }^{3}$ \\ ${ }^{1}$ Universitas Hasanuddin, Indonesia, puspita13200@ gmail.com \\ ${ }^{2}$ Universitas Hasanuddin, Indonesia, hasbirpaserangi@yahoo.co.id \\ ${ }^{3}$ Universitas Hasanuddin, Indonesia, wiwieheryani00@gmail.com
}

Submitted: April 19, 2021; Reviewed: May 25, 2021; Accepted: June 3, 2021

DOI: 10.25041/iplr.v2i2.2319

\begin{abstract}
Default is an omission or negligence, breaking a promise, or violating what has been agreed. One example of an engagement default is case number: 41/Pdt.G/2016/PN.PA. This case began with an agreement between Indoria Hi. The Mpasu brothers were represented by Alfian Chaniago as the authority holder with Lang Hartoyo and Rizal Tjahyadi through a letter of the agreement made by notary XX. Indoria Hi. The Mpasu brothers were unwilling to fulfill the agreement's contents and decided to cancel the agreement unilaterally because they felt they were never involved in the agreement. Based on the case above, a further question arises about how to guarantee legal certainty for authentic deeds and the consequences of the legal deed of agreement that does not follow the procedure. This study is normative legal research, which examines aspects of written law. The approach to the problem in this study is normative juridical, that is, it is based on applicable laws and regulations. In conclusion, the binding deed of the agreement made before a notary does not always go as expected. An authentic deed that does not meet formal requirements is considered imperfect, so it does not have an element of legal certainty. The legal consequence of the deed of the agreement under the power of attorney to sell that is not following the procedure is that the agreement will be null and void.
\end{abstract}

Keywords: Deed, Agreement, Power.

\section{A. Introduction}

The agreement is a translation of the Dutch language, overeenskomst, which means an event where one person promises to another or where two people promise each other to execute an event. ${ }^{1}$ From these events, a legal relationship arises between the two, which is called an engagement. What is meant by an engagement is a legal relationship between two people or two parties, where one party has the right to demand something from the other party, and the other party is obliged to fulfill the claim. ${ }^{2}$ The party who has the right to demand something is

\footnotetext{
${ }^{1}$ Niru Anita Sinaga, "Peranan Asas-Asas Hukum Perjanjian Dalam Mewujudkan Tujuan Perjanjian,” Binamulia Hukum 7, no. 2 (2018): 107-20, https://doi.org/https://doi.org/10.37893/jbh.v7i2.20.

2 Alexander Savelyev, "Contract Law 2.0: 'Smart' Contracts as the Beginning of the End of Classic Contract Law," Information \& Communications Technology Law 26, no. 2 (2017): 116-34, https://doi.org/https://doi.org/10.1080/13600834.2017.1301036.
} 
called the creditor, while the party obliged to fulfill the claim is called the debtor. ${ }^{3}$ Thus the relationship between the engagement and the agreement is that the agreement issues an engagement. Agreements are the most important source that gives birth to engagements and other sources such as law. ${ }^{4}$ Engagements originating from the law are divided into two, namely from the law only and due to human actions. ${ }^{5}$ In the law of engagement, everyone can enter into an engagement based on an agreement, whether it is regulated by law or not. This is called freedom of contract, provided that freedom of contract must be lawful and does not violate the law. ${ }^{6}$

The parties must implement the consented agreement in the engagement. These consented agreements are called achievements. Achievements can be in the form of handing over an object, performing an action, and/or not performing an action. ${ }^{7}$ The engagement will end when the parties have fulfilled the agreed promises. In practice, one of the parties does not comply with what have become its obligations, resulting in the party being in default. ${ }^{8}$ Default is often said to be neglect, breaking a promise, or violating what has been agreed. ${ }^{9}$ This negligent act will cause problems because parties feel aggrieved and demand their rights, which should be fulfilled. ${ }^{10}$ There are three kinds of non-fulfillment of the engagement: ${ }^{11}$

a. The debtor does not fulfill the engagement at all.

b. The debtor is late in fulfilling the engagement.

c. The debtor is wrong or does not deserve to fulfill the engagement.

One case example of an engagement default is case number: 41/Pdt.G/2016/PN.PA. The case began with a lawsuit against a plot of land with an area of $+1.200 \mathrm{~m}^{2}$ located on Jalan Sam Ratulangi, West Besusu Village, East Palu District, Palu City, Central Sulawesi Province. The land is an inherited land whose heir is Indoria Hi. Mpasu and her six siblings. Without the knowledge of the heirs, the land was sold by someone to Lang Hartoyo whose address was at Pa'baeng-baeng Village, Tamalate District, Makassar City-knowing that Lang Hartoyo purchased her land without her consent, Indoria Hi. Mpasu filed a lawsuit with the Palu District Court. After going through the examination process, the Palu District Court granted Indoria Hi. Mpasu's lawsuit through the decision of the Palu District Court Number: 77/Pdt/6/2008/PN.PL. Dissatisfied with Palu District Court's decision, Lang Hartoyo filed an appeal to the Central Sulawesi High Court in Palu. The Central Sulawesi High Court granted his appeal through its decision number: 71/Pdt/2010/PT.Palu. The dispute continues with the cassation action taken by Indoria Hi. Mpasu to the Supreme Court of the Republic of Indonesia in Jakarta. Through the Decree of the Supreme Court of the Republic of Indonesia

\footnotetext{
${ }^{3}$ Subekti Rahayu, Hukum Perjanjian, 4th ed. (Jakarta: Citra Aditya Bhakti, 1987):6.

${ }^{4}$ Ahmadi Miru, Hukum Kontrak Dan Perancangan Kontrak, 8th ed. (Depok: Rajawali Pers, 2018): 1-180.

5 Aluisius Dwi Rachmanto, "Penyelesaian Sengketa Konsumen Akibat Perjanjian Baku Dan Klausula Baku Pasca Keberlakuan Undang-Undang Nomor 21 Tahun 2011 Tentang Otoritas Jasa Keuangan,” Jurnal Hukum \& Pembangunan 48, no. 4 (2018): 826-60, https://doi.org/http://dx.doi.org/10.21143/jhp.vol48.no4.1805.

${ }^{6}$ Wilopo Cahyo Figur Satrio, "Prinsip Timbulnya Perikatan Dalam Perjanjian Jual Beli Berbasis Syariah," Notarius 13, no. 1 (2020): 294-311, https://doi.org/https://doi.org/10.14710/nts.v13i1.30390.

${ }^{7}$ Hartana, "Hukum Perjanjian (Dalam Perspektif Perjanjian Karya Pengusaha Pertambangan Batubara)," Jurnal Komunikasi Hukum 2, no. 2 (2016): 147-82, https://doi.org/http://dx.doi.org/10.23887/jkh.v2i2.8411.

${ }^{8}$ Made Putri Shinta Dewi Hanaya and I Made Sarjana, "Akibat Hukum Wanprestasi Dalam Peralihan Hak Milik Atas Tanah Melalui Perjanjian Tukar Menukar," Kertha Semaya : Journal Ilmu Hukum 7, no. 2 (2019): 1-14, https://ojs.unud.ac.id/index.php/kerthasemaya/article/view/52933.

${ }^{9}$ Oka Setiawan, Hukum Perikatan, 3rd ed. (Jakarta: Sinar Grafika, 2018):19.

${ }^{10}$ Maysha Uri Vatriska and I Wayan Novy Purwanto, "Wanprestasi Dalam Perjanjian Jual Beli Lukisan Di Batu Belah Art Space Klungkung," Kertha Semaya: Journal Ilmu Hukum 2, no. 1 (2018): 3-13, https://ojs.unud.ac.id/index.php/kerthasemaya/article/view/41798.

11 Sedyo Prayogo, "Penerapan Batas-Batas Wanprestasi Dan Perbuatan Melawan Hukum Dalam Perjanjian," Jurnal Pembaharuan Hukum 3, no. 1 (2016): 280-87, https://doi.org/http://dx.doi.org/10.26532/jph.v3i2.1453.
} 
Number: $1063 \mathrm{~K} / \mathrm{Pdt} / 2012$, Indoria Hi. Mpasu was granted; thus, Lang Hartoyo was determined as the losing party in the dispute.

Lang Hartoyo filed a judicial review or Peninjauan Kembali (PK). In the period of PK, Alfian Chaniago (brother-in-law of Indoria Hi. Mpasu) representing Indoria Hi. Mpasu and their brothers contacted Lang Hartoyo and Rizal Tjahyadi with an offer for a peaceful dispute settlement. In several meetings between Alfian Chaniago, Lang Hartoyo and Rizal Tjahyadi, it turned out that Alfian Chaniago had a power of attorney to sell dated October 13, 2014, given by Indoria Hi. Mpasu and her relatives, Gusman Maarif, Mohamad Juanda, Abd. Rahman, Wahyuni, Kasman Kasim, Sandra, Abd. Azis, Dewi Anggriyani, Riski Kasim, and Nurayni Kasim. The power of attorney to sell is made by "XX", a notary/Land Deed Making Officer or Pejabat Pembuat Akta Tanah (PPAT) in Palu.

Several meetings between Alfian Chaniago and Lang Hartoyo and Rizal Tjahyadi resulted in an agreement to Indoria Hi. Alfian Chaniago only represented the Mpasu brothers as the power holder with Lang Hartoyo and Rizal Tjahyadi. The agreement letter was then made by notary XX, which stated that Lang Hartoyo, Rizal Tjahyadi, Indoria Hi. Mpasu and her relatives each consent to offer, sell, mutually agree, and sign the land deed of sale and purchase owned by Indoria Hi. Mpasu and her relatives are covering an area of $+1.200 \mathrm{~m}^{2}$. Both parties are aware the land is located on Jalan Sam Ratulangi, West Besusu Village, East Palu District, Palu City and complete with data on the land boundary.

Indoria Hi. Mpasu and his brothers were unwilling to fulfill the terms of the agreement and decided to cancel the agreement unilaterally without notifying and seeking prior approval from Lang Hartoyo and Rizal Tjahyadi. Moreover, Indoria Hi. Mpasu and their brothers did not apply to the judge. Therefore they cancelled the agreement without a judge's decision. Lang Hartoyo and Rizal Tjahyadi consider that Indoria Hi. Mpasu and his brothers' unilaterally cancelling this agreement is an act of default (breaking a promise). Indoria Hi. Mpasu and his relatives later became the object of a lawsuit from Lang Hartoyo and his friends to the Palu District Court.

Based on this fact, the researcher focuses on the latest lawsuit filed by Lang Hartoyo with case number: 41/Pdt.G/2016/PN.PA is the main of this study. The primary substance that caused the lawsuit made by Lang Hartoyo, in this case, lies in the legal force of the notary deed made by notary XX. The researcher argues uncertainty in the content of the agreement made by the parties, causing differences in perception between the parties of the agreement in the notarial deed. Lang Hartoyo and his colleagues argued in their lawsuit that Indoria Hi. Mpasu as Defendants II to Defendants XII defaulted, while Indoria Hi. Mpasu, along with the other defendants, argued that they had never entered into an agreement with Lang Hartoyo in the presence of notary XX even in his answer to the question of who was notary XX. This indicates that a notarial deed that is legally categorized as an authentic deed still can cause legal problems because it is not accepted by the parties involved in it.

In this case, it is necessary to review and evaluate the laws and regulations, especially the Notary Position Regulation or Peraturan Jabatan Notaris (PJN). This is important to provide firm and clear guarantees for the protection and legal certainty of authentic deeds issued by a notary. Based on the case, the problem in this study is how to guarantee legal certainty for authentic deeds? And what are the legal consequences of the agreement under the power of attorney that is not following the procedure? This research is normative legal research, namely research that examines aspects of written law. The approach to the problem in this study uses a normative juridical approach, namely an approach based on applicable laws and 
regulations. ${ }^{12}$ Therefore, this research will examine and analyze the laws and regulations and decisions related to legal problems that arise in this research.

\section{B. Discussion}

\section{Legal Assurance of the Authentic Deed}

According to Gustav Radbruch, there are three law objectives: justice, expediency, and legal certainty. To create legal certainty, legal order, and legal protection, doing an authentic deed is required to fulfill the provisions in the legislation. Subsequently, the meaning of legal certainty, legal order, and legal protection will be actualized in fulfilling the rights and obligations of the parties who bind themselves in the deed. ${ }^{13}$

According to Article 1868 of the Civil Code, three main elements must be met to issue an authentic deed. Firstly, the form of the authentic deed must be determined by law. Secondly, it is made by or before a public official. Thirdly, the three deeds are done by or before a public official in the area of his authority. In carrying out his functions and duties, a notary must use the principle of prudence because the deed he issued must be accounted for following his profession. In doing an authentic deed, a notary makes a binding agreement between the seller and the buyer. This is done to protect the parties from legal uncertainty and prevent unwanted legal consequences. ${ }^{14}$ The guarantee of legal certainty expected from an authentic deed provides parties' certainty and protection following their respective positions in the agreement made before a notary. ${ }^{15}$

In general, an agreement is a legal relationship between one or more parties and two parties that bind themselves together. The definition of an agreement is explained in Article 1313 of the Civil Code that an agreement is an act where one or more people bind themselves to one or more other people. Furthermore, the agreement made as referred to in article 1313 has legal force as stated in the provisions of article 1338 paragraph (1), which stipulates that every agreement made legally applies as law for the parties who make it. Considering these two provisions, it guarantees that the agreement made by the parties provides legal certainty, legal order, and legal protection as long as the agreement is made based on the conditions specified in Article 1320 of the Civil Code.

The provisions of article 1313, article 1338 and article 1320 of the Civil Code adhere to the principle of freedom of contract for the parties who agree to do something or not to do something. The role of a notary in making a deed of agreement is signed. As a public official, the notary must be professional, one of which is to bridge the parties' interests that bind themselves in the agreement to provide legal certainty guarantees for the fulfillment of their rights and obligations as agreed in the agreement. ${ }^{16}$ One of the legal remedies that the notaries must consider in binding the agreement made before him must be attended by two witnesses. Still, in practice, the process of signing the binding deed of the sale and purchase agreement is

\footnotetext{
12 Kornelius Benuf and Muhamad Azhar, "Metodologi Penelitian Hukum Sebagai Instrumen Mengurai Permasalahan Hukum Kontemporer," Gema Keadilan 7, no. $1 \quad$ (2020): 23, https://doi.org/https://doi.org/10.14710/gk.7.1.20-33.

13 Achmad Ali, Menguak Tabir Hukum; Suatu Kajian Filosofis Dan Sosiologis (Jakarta: Gunung Agung, 2002).

14 Paul MacMahon, "Conflict and Contract Law," Oxford Journal of Legal Studies 38, no. 2 (2018): 1-29, https://doi.org/doi:10.1093/ojls/gqy011.

15 Made Ara Denara Asia Amasangsa and I Made Dedy Priyanto, "Perjanjian Pengikatan Jual Beli (PPJB) Dalam Transaksi Peralihan Hak Atas Tanah Dan/Atau Bangunan," Kertha Semaya: Journal Ilmu Hukum 8, no. 1 (2019): 1-18, https://ojs.unud.ac.id/index.php/kerthasemaya/article/view/55865.

16 Ingeborg Schwenzer, "Global Unification of Contract Law," Uniform Law Review 21, no. 1 (2016): 60-74, https://doi.org/https://doi.org/10.1093/ulr/unw005.
} 
carried out without the presence of witnesses. A notary carries out the process that should be reading the deed before the parties in the presence of witnesses. ${ }^{17}$

The binding of an agreement with the principle of freedom contains promises of the parties to transfer rights to other parties so that the transfer of rights obtains certainty, order and legal protection. The importance of legal events or actions in the form of transfer of rights to other parties made before a notary as outlined in the form of an authentic deed of urgency to assure that the event or action is authentic written evidence regarding the circumstances, events or legal actions carried out through the office. Certain; thus, an authorized official is needed to do so. ${ }^{18}$

Although, the form of a deed of agreement does not exist in the Civil Code. The development of community needs requires that the agreement be born on the principle of freedom of contract. The binding of the sale and purchase agreement deed is made authentically to provide legal certainty, order and legal protection for the parties. Through a notary, the parties can formulate the contents of the clause following the interests in the agreement's binding. However, the binding of the deed of the agreement made in the presence of a notary does not always go as expected. As a result, agreements are often found to be cancelled, either by one party or through a court decision, so that the authentic deed that a notary has issued does not guarantee legal certainty, order and legal protection.

The binding of an agreement in an authentic deed carried out by a notary without the presence of witnesses and even without the presence of one of the parties is a practice that is not following the provisions of Law Number 2 of 2014 concerning Amendments to Law Number 30 of 2004 concerning Notary Positions, namely at least two witnesses. Thus, at the time of carrying out the binding of the agreement, the intent of Article 40 paragraph (1), which requires the presence of witnesses before a notary, will produce an authentic deed that does not guarantee legal certainty, order and legal protection.

In contrast to Law Number 2 of 2014 concerning Amendments to Law Number 30 of 2004 concerning the Position of a Notary, the provisions of Article 1868 of the Civil Code stipulates that an authentic deed is a deed made in a form determined by law before a public official who has the authority, at the place where the deed was done. Taking into account the provisions of the article, it is formulated that an authentic deed must meet the formal requirements, namely:

a. Established in the form prescribed by law;

b. Established by and in front of the general office;

c. A deed is done by or before an official public office at the place where the deed is done.

The juridical consequences of authentic deeds that do not meet the formal requirements mentioned above are considered imperfect. They thus do not have elements of legal certainty, order and legal protection. In addition to the formal requirements, the issuance of an authentic deed must meet material requirements, including:

a. Contains The Agreement Of The Parties;

b. The Contents Of The Statement Of Legal Action; And

c. The making of the deed is intentionally intended as evidence.

\footnotetext{
${ }^{17}$ Dwi Merlyania, Annalisa Yahanana, and Agus Trisaka, "Kewajiban Pembacaan Akta Otentik Oleh Notaris Di Hadapan Penghadap Dengan Konsep Cyber Notary," Repertorium: Jurnal Ilmiah Hukum Kenotariatan 9, no. 1 (2020): 36-47, https://doi.org/10.28946/rpt.v9i1.358.

${ }^{18}$ Agustiro Nugroho Aribowo, "Kepastian Hukum Pengikatan Akta Perjanjian Jual Beli Di Hadapan Notaris Tanpa Dihadiri Para Saksi," Jurnal Surya Kencana Satu : Dinamika Masalah Hukum Dan Keadilan 11, no. 1 (2020): 85-102, https://doi.org/http://dx.doi.org/10.32493/jdmhkdmhk.v11i1.5609.
} 
The material requirements mentioned above contain the interpretation that the authentic deed is made based on the agreement of the parties, ${ }^{19}$ So that an authentic deed must explain the content of interest in the form of legal acts, and the deed is intended as a means of evidence. On the form of an agreement made in writing through an authentic act has meaning as a means of evidence when one of the parties commits default. Thus, the agreement made in writing through an authentic deed is a means of proof and fulfills the conditions for the existence of the event (agreement). This study is interesting to find out the legal certainty of an authentic deed in the absence of one of the parties, whether it can be seen as fulfilling the formal and material requirements. Therefore, the parties' agreement made before a notary in the form of an authentic deed has legal certainty for the parties in fulfilling their rights and obligations.

In exercising its authority, as regulated in the provisions of Article 15 paragraph (1) of the Law of the Republic of Indonesia Number 2 of 2014 concerning Amendments to the Law of the Republic of Indonesia Number 30 of 2004 concerning the Position of a Notary. As stipulated in the Law of the Republic of Indonesia Number 30 of 2004 concerning the position of a notary, which has been amended by the Law of the Republic of Indonesia Number 2 of 2014 concerning Amendments to the Law of the Republic of Indonesia Number 30 of 2004 concerning the Position of a Notary, that a notary is a public official authorized to make authentic deeds and other authorities as referred to in the law. This law states that notaries are authorized to do authentic deeds regarding all acts, agreements, and stipulations required by legislation or required by interested parties to be stated in authentic deeds, guarantee certainty of the date of doing deeds, keep deeds, provide Grosse copies and collections of the deed, all of which during the making of the deed are also not assigned or exempted to other offices or other persons prescribed by law.

The authority possessed by a notary as regulated in the law mentioned above is intended to provide legal protection and certainty to a notary in carrying out his duties and authorities. This is in line with the general explanation of the Law of the Republic of Indonesia Number 2 of 2014 concerning Amendments to the Law of the Republic of Indonesia Number 30 of 2004 concerning the Position of Notary, which explains that: ${ }^{20}$

Notaries, as public officials who carry out the profession in providing legal services to the public, need protection and guarantees to achieve legal certainty. Guarantees of protection and guarantees of achieving legal certainty for the implementation of the duties of a notary have been regulated in Law Number 30 of 2004 concerning the position of a notary. However, several provisions in the law are no longer following legal developments and the needs of the community, so that changes need to be made, which are also intended to further emphasize and strengthen the duties, functions, and authorities of notaries as officials who carry out public services, as well as synchronization with the other laws.

As a legal product with a clear purpose, to provide notaries protection with the creation of legal certainty for the products it makes. Therefore, it is necessary to conduct a review to see and juridical examine the facts that occur, what are the objectives contained in the lawimplemented following the basic philosophy so that the benefits can be felt for the legal interests of the community and the public interest. Following the primary substance in this study, the researcher intends to review several legal aspects regarding the deed issued by a notary. The deed of agreement was born based on the power to sell, mainly in terms of the

\footnotetext{
${ }^{19}$ Nataliia Filatova, "Smart Contracts from the Contract Law Perspective: Outlining New Regulative Strategies," International Journal of Law and Information Technology 28, no. 3 (2020): 217-42, https://doi.org/https://doi.org/10.1093/ijlit/eaaa015.

${ }^{20}$ Law of the Republic of Indonesia Number 2 of 2014 Concerning Amendments to Law of the Republic of Indonesia Number 30 of 2004 Concerning Notary Position (2014).
} 
legal aspects and the legal consequences arising as a result of the birth of a deed that not following the procedures and standards regulated in the legislation.

In the laws and regulations, it is expressly regulated that an authentic deed is evidence with a very high value and is perfect from other evidence. There are several reasons so that an authentic deed is the only evidence that has a very high and perfect value from other evidence, including an underhand deed, namely:

a. The authentic deed is written evidence as referred to in Article 1868 BW, 164 RIB and 283 RDS;

b. The authentic act was from the very beginning deliberately made as a tool of evidence;

c. Authentic Acts are done by and in the presence of a State office designated by law;

d. Based on Article $1870 \mathrm{BW}$ or $165 \mathrm{RIB}$, an authentic deed provides between the parties, their heirs and those who have rights from them a perfect proof of what is contained therein;

e. The authentic deed is not only perfect evidence but also binding evidence. It is perfect proof in the sense that it does not require any additional proof. While binding what is written must be believed by the judge, it must be considered trustworthy, as long as the untruth is not proven.

As evidence, an authentic deed has 3 strengths, namely: ${ }^{21}$

a. The power of outward proof (uitwendige bewijskracht). The physical ability of a notary deed is the ability of the deed itself to prove its validity as an authentic deed (Acta Publica probant sese ipsa).

b. The power of formal proof (formele bewijskracht). The notary deed must provide certainty that an event and fact mentioned in the deed was actually carried out by a notary or explained by the parties appearing at the time stated in the deed by the procedures specified in the making of the deed.

c. The power of material proof (materiele bewijskracht). This means that what is stated in the deed is valid evidence against the parties who made the deed or those who have rights and are generally applicable unless there is evidence to the contrary (tegenbewijs).

Considering the provisions of Article 15 paragraph (1), as described by the researcher in the previous section, a conclusion is drawn that the deed of agreement is categorized as part of an authentic deed. Regarding the civil case Number: 41/Pdt.G/2016/PN.PA dated August 22, 2016, which is the object of the juridical review in this study, there is a power to sell which gave birth to an agreement between Alfian Chaniago and Lang Hartoyo, both of which were issued by a notary and became the main problem is the dispute. This is seen by the researchers that the deed of agreement issued by a notary violates certainty as aspired to in the Law of the Republic of Indonesia Number 2 of 2014 concerning Amendments to the Law of the Republic of Indonesia Number 30 of 2004 concerning the Position of a Notary.

\section{Legal Consequences of The Deed Of Agreement Under The Authorization To Sell That Are Not Following The Procedure}

Article 1868 of the Civil Code stipulates that an authentic deed is determined by law by or before public officials who have the power to do where the deed was done. Taking into account the provisions of the article, it is formulated that an authentic deed must meet the formal requirements, namely:

a. Made in the form determined by law;

b. Made by and before a public official;

\footnotetext{
${ }^{21}$ Christin Sasauw, “Tinjauan Yuridis Tentang Kekuatan Mengikat Suatu Akta Notaris,” LEX PRIVATUM 3, no. 1 (2015): 98-109.
} 
c. Deed made by or before a public official authorized to do so and the place where the deed was done.

The juridical consequences of authentic deeds that do not meet the formal requirements mentioned above are considered imperfect. They thus do not have elements of legal certainty, order and legal protection. In addition to the formal requirements, the issuance of an authentic deed must meet material requirements, including:

a. contains the agreement of the parties

b. the contents of the statement of legal action; and

c. the making of the deed is intentionally intended as evidence.

The material requirements mentioned above contain the interpretation that the authentic deed is made based on the agreement of the parties, regarding the form of an agreement made in writing through an authentic deed; it has meaning as evidence if one of the parties is in default. So that the authentic deed must explain the contents of the interest in the form of legal action and the deed is intended as evidence. Thus, the agreement made in writing through an authentic deed is a means of proof and fulfills the conditions for the existence of the event (agreement).

As stated by the researcher in the results section of the study, the dispute has been taken through the Court of First Level to the level of cassation in the Supreme Court, which was won by Indoria Hi. Mpasu as the defendant in the Court of First Level, which Lang Hartoyo sued. The legal uncertainty referred to by the researcher is the arguments presented by Indoria Hi. Mpasu in detail as follows:

1. Hi. Mpasu never gave power of attorney to Alfian Chaniago in a notarial or notarized manner;

2. The making of an authentic deed, both the power of attorney to sell and the deed of agreement issued by notary XX, is not recognized by Indoria Hi. Mpasu with reasons:

a. Never been invited by a notary in the making;

b. He and the other defendants did not know or even saw the face of notary XX

3. Even if the basis for issuing the deed of agreement is the result of meetings between Alfian Chaniago and Lang Hartoyo, it is not groundless because Indoria Hi does not recognize these meetings. Mpasu as Defendant II to Defendant XII.

4. The deed of the agreement made by Alfian Chaniago with Lang Hartoyo was never shown to Indoria Hi. Mpasu as Defendant II to Defendant XII;

5. The deed of the agreement made by Alfian Chaniago with Lang Hartoyo was never shown to Indoria Hi. Mpasu as Defendant II to Defendant XII;

6. Indoria Hi. Mpasu and the other defendants never wanted to have anything to do with Lang Hartoyo. They did not want to ally with Lang Hartoyo, whom he considered to have usurped his rights and was declared the loser in the decision of the Supreme Court of the Republic of Indonesia.

7. Indori Himpasu and the other defendants never felt they decided/annulled the agreement unilaterally because of Indoria Hi. Mpasu never agreed with Lang Hartoyo.

Based on the arguments put forward by both Lang Hartoyo as the plaintiff and by Indoria, Hi. Mpasu as the defendant, the judge who tried the aqua case in his legal considerations described by the researcher in full opinion as follows:

1. Legal evidence is also referred to as a deed. Whereas several functions of a letter (deed) in several events or legal actions of a deed are stipulated as an essential requirement (formality causa) without a deed, it is considered that the legal actions carried out do not meet the formal requirements;

2. In terms of asset quality, it is divided into several forms of the deed, each of which has a different power of proof, namely: 
a. An authentic deed as regulated in Article 1868 of the Civil Code that an authentic deed is a deed made in the form determined by law by or before a public official authorized for that at the place where the deed was done;

b. Underhanded deed as formulated in Article 1874 of the Civil Code Article 286 RBG that writings and deeds signed under the hands are not made and signed before an authorized official but are made by a person or parties themselves.

3. In this case, Lang Hartoyo had submitted documentary evidence, which, after being scrutinized by the Panel of Judges, is concluded as a deed made before a public official.

4. Because the evidence of the letter is based on the argument that Lang Hartoyo's lawsuit was made before the authorized official for that, but because of the truth of the authentic deed, Indoria Hi denied the truth. Mpasu as the party whose name is in the deed of power of attorney as the giver of power to Alfian Chaniago as the recipient of a power of attorney, Lang Hartoyo must be able to prove the truth of the evidence of a power of attorney made before the authorized official for that and prove that the deed has been done on a legal basis and provisions of laws that apply before the Court;

5. If the authentic deed made is carried out by an incompetent and unauthorized official or the form is defective, then according to Article 1869 of the Civil Code, the deed is invalid or does not meet the formal requirements as an authentic deed;

6. In the field of civil law, by notaries, generally authentic deeds concerning civil matters are made before a notary. This is confirmed in Article 1 of the Notary Position Regulation (PJN) (S.1860 Number 3) which states that notaries are special public officials authorized to make authentic deeds regarding all agreements and stipulations based on the law or desired by interested persons; Several formal requirements must be met to support the validity of the authentic deed or notarial deed which is cumulative and not alternative so that if one of the conditions is not met, the authentic deed is invalid and has no evidentiary power to prove the disputed case;

7. The formal requirements are:

a. Made before an authorized official according to law;

b. Attended by the parties regarding the decision of the Supreme Court of the Republic of Indonesia Number $3556 \mathrm{~K} / \mathrm{Pdt} / 1985$ and the requirement regarding the presence of the parties to be present before an official is also regulated in Article 24 PJN (S 1860-3);

c. The making of the deed must also be attended by two witnesses who, based on the provisions of Article $22 \mathrm{PJN}$, are witnesses who are capable and understand the language in the deed;

d. The notary reads the deed in front of the witnesses;

e. Signed by all parties immediately after the deed is read so that if there is a violation of the signing, the deed is invalid and has nopower as an authentic deed but only has value as a private deed.

8. Because in the examination of this case, Indoria Hi. Mpasu stated the denial of the deed of power of attorney argued by Lang Hartoyo as a power of attorney for Alfian Chaniago in agreeing with Lang Hartoyo's party. In contrast, Lang Hartoyo's party was unable to prove the denial of Indoria Hi. Mpasu and the truth that can be used as a legal basis as transfer of power by Indoria Hi. Mpasu, together with the other defendants before a notary, told Alfian Chaniago about the validity of the deed of power of attorney made before the notary through trial evidence, the authentic deed in the form of a power of attorney was not assessed by the judge as an authentic deed. Likewise, the deed that arises from the power of attorney that follows it does not have solid and perfect proof of the power and is binding on the parties; 
9. A power of attorney, which is used as the basis for the issuance of the agreement letter and statement letter as evidenced by Lang Hartoyo's letter, in this case, is considered not to have valid evidentiary power. Furthermore, the proof of the agreement and statement letter is also considered insufficient evidentiary power. So that the evidence of this letter is of no value to uphold the argument of Lang Hartoyo's lawsuit;

10. During the examination of this case, Alfian Chaniago was never present, nor did he state the reasons for his absence and did not give the power to represent his interests in this case, then Alfian Chaniago is deemed not to have exercised his rights;

11. By not having a valid proof value in a power of attorney, the deed of agreement issued between Alfian Chaniago and Lang Hartoyo also does not have legally binding force, so what Lang Hartoyo argues is a form of default by Indoria Hi. Mpasu and the other defendants should be declared rejected.

Comparing the arguments in the plaintiff's lawsuit, the arguments put forward by the defendant and the judge's view in his decision, the researcher is of the view that the authentic deed issued by notary XX is in the form of a power of attorney to sell to Alfian Chaniago. The Deed of Agreement between Lang Hartoyo and Alfian Chaniago is procedural. This is caused because it contradicts the Supreme Court's decision The Republic of Indonesia Number 3556 $\mathrm{K} / \mathrm{Pdt} / 1985$ and the provisions of Article $24 \mathrm{PJN}$ (S 1860-3) concerning the necessity of the presence of the parties before a notary and the appearers must be known or introduced to the notary by two witnesses. The researcher's view is based on the argument proposed by Indoria Hi. Mpasu stated that a notary had never invited him to make the power to sell or the deed of agreement, even Indoria Hi. Mpasu, in this case, argued that he and the other defendants did not know the face of notary XX. As a result, the author thinks that the deed issued by notary $\mathrm{XX}$ does not have the power of certainty. This is in line with the judge's view in his ruling, which stated that the deed submitted by Lang Hartoyo was the basis for declaring that Indoria Hi. Mpasu, in default, should be rejected because it does not have binding evidence.

After analyzing the authentic deed certainty element, in this case, the researcher will then analyze other facts revealed through the arguments put forward by Lang Hartoyo as the plaintiff. Which fact, Lang Hartoyo as the plaintiff in the argument of his lawsuit, said that Indoria Hi. Mpasu, along with the other defendants, cancelled/decided the aquo agreement without an application to the judge and prior approval from the judge.

Against this argument, the researcher first wants to discuss the legal force of an agreement seen from the provisions of the legal terms of the agreement as regulated in Article 1320 of the Civil Code. The researcher saves that both the agreement made under the hand and the agreement made before a notary (authentic) are both subject to these provisions considering that the provisions of Article 1320 of the Civil Code regulate the terms of the validity of the agreement.

The deed of the agreement was made based on the power to sell by notary XX in a civil case Number: 41/Pdt.G/2016/PN.PA dated August 22, 2016, which is the object of this study, is seen by researchers as an agreement that deviates from the legal requirements of an agreement. This is evidenced by the theorem Indoria Hi. Mpasu as a defendant who said that a notary never invited him in making a power of attorney to sell or a deed of agreement even he and the other defendants did not know and had never seen the face of notary XX. Suppose the argument is confronted with the provisions of Article 1320 of the Civil Code. The researcher believes that the deed of the agreement made by a notary does not meet the terms of the parties' agreement with Indoria Hi's consideration. Mpasu denies that he has never been confronted with a notary and other related parties.

Juridically, the conditions for a valid agreement as regulated in Article 1320 of the Civil Code consist of 2 conditions, namely subjective and objective conditions. The subjective and 
objective conditions referred to are cumulative and are not alternative. This means that both conditions must be met perfectly - the description of the two conditions in question areas. Subjective requirements include agreement and skills. At the same time, the objective requirements include a specific object and for lawful reasons.

If one of these conditions is not met, it will have different legal consequences. The absence of an agreement or non-fulfillment of skills will result in the agreement being cancelled. This means that the agreement is still valid as long as the judge's decision has not been issued, declaring the agreement void. In contrast to subjective conditions, the legal consequences that arise if one of the objective conditions is not met, the agreement is null and void. ${ }^{22}$ This means the agreement has been made in the form of an authentic deed. It must be seen as an agreement with no binding legal force.

The difference in the arguments between Lang Hartoyo as the plaintiff and Indoria Hi. Mpasu, as the second defendant, has stated the denial of the deed of power of attorney argued by Lang Hartoyo as the plaintiff as a power of attorney for Alfian Chaniago as the first defendant in agreeing with Lang Hartoyo. At the same time, Lang Hartoyo was unable to prove the denial of Indoria Hi. Mpasu, together with other defendants before a notary, told Alfian Chaniago about the validity of the deed of power of attorney made before the notary through trial evidence, the authentic deed in the form of a power of attorney was not assessed by the judge as an authentic deed. Likewise, the deed that arises from the power of attorney that follows it does not have solid and perfect proof of the power and is binding on the parties. They were paying attention to the denial through the arguments put forward by Indoria Hi. Mpasu. The researcher believed that there was no need to make an effort to determine the cancellation of the agreement to the Court, as argued by Lang Hartoyo because Indoria Hi. Mpasu was never involved as a party to the agreement proposed by Lang Hartoyo.

\section{Conclusion}

From the discussions above, key findings emerge from this study are the following:

1. In practice, the binding of the deed of the agreement made before a notary does not always run as expected. Authentic deeds that do not meet formal requirements are considered imperfect, so they are often considered not to have elements of legal certainty, order and legal protection. As a result, the agreement is cancelled, either by one of the parties or through a court decision.

2. The legal consequences of the deed of the agreement under the power of attorney to sell that are not following the procedure. Namely, the agreement will be null and void, so that in the case with Case Number: 41/Pdt.G/2016/PN.PA, there is no need to try to determine the cancellation of the agreement to the Court as argued by Lang Hartoyo because Indoria Hi. Mpasu was never involved as a party to the agreement.

\section{BIBLIOGRAPHY}

Ali, Achmad. Menguak Tabir Hukum; Suatu Kajian Filosofis Dan Sosiologis. Jakarta: Gunung Agung, 2002.

Amasangsa, Made Ara Denara Asia, and I Made Dedy Priyanto. "Perjanjian Pengikatan Jual Beli (PPJB) Dalam Transaksi Peralihan Hak Atas Tanah Dan/Atau Bangunan." Kertha Semaya: Journal Ilmu Hukum 8, no. 1 (2019): 1-18. https://ojs.unud.ac.id/index.php/kerthasemaya/article/view/55865.

Aribowo, Agustiro Nugroho. "Kepastian Hukum Pengikatan Akta Perjanjian Jual Beli Di

\footnotetext{
${ }^{22}$ Mark Giancaspro, "Is a 'Smart Contract' Really a Smart Idea? Insights from a Legal Perspective," Computer Law \& Security Review 33, no. 6 (2017): 825-35, https://doi.org/doi:10.1016/j.clsr.2017.05.007.
} 
Hadapan Notaris Tanpa Dihadiri Para Saksi.” Jurnal Surya Kencana Satu: Dinamika Masalah Hukum Dan Keadilan 11, no. 1 (2020): 85-102. https://doi.org/http://dx.doi.org/10.32493/jdmhkdmhk.v11i1.5609.

Benuf, Kornelius, and Muhamad Azhar. "Metodologi Penelitian Hukum Sebagai Instrumen Mengurai Permasalahan Hukum Kontemporer." Gema Keadilan 7, no. 1 (2020): 23. https://doi.org/https://doi.org/10.14710/gk.7.1.20-33.

Filatova, Nataliia. "Smart Contracts from the Contract Law Perspective: Outlining New Regulative Strategies." International Journal of Law and Information Technology 28, no. 3 (2020): 217-42. https://doi.org/https://doi.org/10.1093/ijlit/eaaa015.

Giancaspro, Mark. "Is a 'Smart Contract' Really a Smart Idea? Insights from a Legal Perspective." Computer Law \& Security Review 33, no. 6 (2017): 825-35. https://doi.org/doi:10.1016/j.clsr.2017.05.007.

Hanaya, Made Putri Shinta Dewi, and I Made Sarjana. "Akibat Hukum Wanprestasi Dalam Peralihan Hak Milik Atas Tanah Melalui Perjanjian Tukar Menukar." Kertha Semaya: $\begin{array}{llllll}\text { Journal Ilmu Hukum 7, no. } 2019) \text { : } & \text { 1-14. }\end{array}$ https://ojs.unud.ac.id/index.php/kerthasemaya/article/view/52933.

Hartana. "Hukum Perjanjian (Dalam Perspektif Perjanjian Karya Pengusaha Pertambangan Batubara)." Jurnal Komunikasi Hukum 2, no. 2 (2016). https://doi.org/http://dx.doi.org/10.23887/jkh.v2i2.8411.

Law of the Republic of Indonesia Number 2 of 2014 concerning Amendments to Law of the Republic of Indonesia Number 30 of 2004 concerning Notary Position (2014).

MacMahon, Paul. "Conflict and Contract Law." Oxford Journal of Legal Studies 38, no. 2 (2018): 1-29. https://doi.org/doi:10.1093/ojls/gqy011.

Merlyania, Dwi, Annalisa Yahanana, and Agus Trisaka. "Kewajiban Pembacaan Akta Otentik Oleh Notaris Di Hadapan Penghadap Dengan Konsep Cyber Notary." Repertorium: Jurnal Ilmiah Hukum Kenotariatan 9, no. 1 (2020): 36-47. https://doi.org/10.28946/rpt.v9i1.358.

Miru, Ahmadi. Hukum Kontrak Dan Perancangan Kontrak. 8th ed. Depok: Rajawali Pers, 2018.

Prayogo, Sedyo. "Penerapan Batas-Batas Wanprestasi Dan Perbuatan Melawan Hukum Dalam Perjanjian.” Jurnal Pembaharuan Hukum 3, no. 1 (2016): 280-87. https://doi.org/http://dx.doi.org/10.26532/jph.v3i2.1453.

Rachmanto, Aluisius Dwi. "Penyelesaian Sengketa Konsumen Akibat Perjanjian Baku Dan Klausula Baku Pasca Keberlakuan Undang-Undang Nomor 21 Tahun 2011 Tentang Otoritas Jasa Keuangan." Jurnal Hukum \& Pembangunan 48, no. 4 (2018): 826-60. https://doi.org/http://dx.doi.org/10.21143/jhp.vol48.no4.1805.

Rahayu, Subekti. Hukum Perjanjian. 4th ed. Jakarta: Citra Aditya Bhakti, 1987.

Sasauw, Christin. "Tinjauan Yuridis Tentang Kekuatan Mengikat Suatu Akta Notaris." LEX PRIVATUM 3, no. 1 (2015): 98-109.

Satrio, Wilopo Cahyo Figur. "Prinsip Timbulnya Perikatan Dalam Perjanjian Jual Beli Berbasis Syariah." Notarius 13, no. 1 (2020). https://doi.org/https://doi.org/10.14710/nts.v13i1.30390.

Savelyev, Alexander. "Contract Law 2.0: 'Smart' Contracts as the Beginning of the End of Classic Contract Law." Information \& Communications Technology Law 26, no. 2 (2017): 116-34. https://doi.org/https://doi.org/10.1080/13600834.2017.1301036.

Schwenzer, Ingeborg. "Global Unification of Contract Law." Uniform Law Review 21, no. 1 (2016): 60-74. https://doi.org/https://doi.org/10.1093/ulr/unw005.

Setiawan, Oka. Hukum Perikatan. 3rd ed. Jakarta: Sinar Grafika, 2018.

Sinaga, Niru Anita. "Peranan Asas-Asas Hukum Perjanjian Dalam Mewujudkan Tujuan Perjanjian." Binamulia Hukum 7, no. 2 (2018): 107-20. 
https://doi.org/https://doi.org/10.37893/jbh.v7i2.20.

Vatriska, Maysha Uri, and I Wayan Novy Purwanto. "Wanprestasi Dalam Perjanjian Jual Beli Lukisan Di Batu Belah Art Space Klungkung." Kertha Semaya: Journal Ilmu Hukum 2, no. 1 (2018): 3-13. https://ojs.unud.ac.id/index.php/kerthasemaya/article/view/41798. 
